\title{
REVIEW
}

\section{Regulatory T cells: immune suppression and beyond}

\author{
Yisong Y Wan
}

Foxp3-expressing regulatory T cells (Tregs) were originally identified as critical in maintaining self-tolerance and immune homeostasis. The immunosuppressive functions of Tregs are widely acknowledged and have been extensively studied. Recent studies have revealed many diverse roles of Tregs in shaping the immune system and the inflammatory response. This review will discuss our efforts as well as the efforts of others towards understanding the multifaceted function of Tregs in immune regulation.

Cellular \& Molecular Immunology (2010) 7, 204-210; doi:10.1038/cmi.2010.20; published online 12 April 2010

Keywords: Foxp3; Treg; immunosuppression and plasticity

\section{INTRODUCTION}

Mammals have evolved complex immune strategies to fight foreign pathogens and to maintain health. Adaptive and innate immunity are the two fundamental components of the immune response. Together, they form a defensive front against pathogens. Innate immunity is mediated mainly by macrophages and dendritic cells (DCs), which recognize classes of microorganisms. $\mathrm{T}$ and $\mathrm{B}$ cells comprise the major task force carrying out the adaptive immune response, and they have highly antigen-specific surface receptors. Most $\mathrm{T}$ cells recognize specific antigens and then differentiate into effector $\mathrm{T}$ cells to promote immune responses. By using quasi-random recombination mechanisms, thymus-derived $\mathrm{T}$ cells can potentially generate infinite numbers of specificities that are reactive to foreign and self-antigens. Self-reactive $\mathrm{T}$ cells can cause autoimmune diseases in the host if they are not tightly controlled. Multiple processes therefore are in place to suppress the generation or the function of self-reactive T cells. Self-reactive T cells can be deleted in the thymus as well as in the periphery. Such elimination processes are nevertheless incomplete, resulting in small populations of mostly low-affinity self-reactive $\mathrm{T}$ cells in the periphery that can potentially initiate an autoimmune response. Fortunately, active immunosuppressive mechanisms exist to suppress these autoreactive $\mathrm{T}$ cells. Great progress has been made in understanding the cellular and molecular components of immunosuppression. Active immunosuppression is mediated mostly through either cytokines or specialized cells. The immunosuppressive cells, previously called suppressor cells ${ }^{1}$ and now usually termed regulatory T cells (Tregs), play critical roles in suppressing the immune response. For years, much effort has been devoted to investigating the immunosuppressive functions of Tregs under normal and immunopathological conditions. Recently, increasing evidence suggests that Tregs might also turn into effector $\mathrm{T}$ cells that may promote immune responses. Thus, while Tregs are mainly viewed as critical mediators for immunosuppression, they in fact possess many diverse functions in immune regulation. Here we will review the evolution of our views on the functions of Tregs.

\section{Tregs AND DOMINANT IMMUNOSUPPRESSION}

The concept of immunosuppression was proposed by Gershon et al. ${ }^{1-3}$ in the early 1970s. The inability to identify the cell types performing immunosuppression impeded the validation of this concept and hindered development in this research area. It was not until a study performed by Sakaguchi et al. in 1995 that a subset of T cells with markedly increased expression of CD25 was discovered, named suppressor T cells, and later referred to as regulatory T cells (Tregs). ${ }^{4}$ In recent years, substantial progress has been made in identifying different types of Tregs as well as in understanding how these cells are generated and function. Based on cell surface markers or cytokine secretion profiles, Tregs can be generally grouped into two categories: naturally occurring Tregs (nTregs) and induced Tregs (iTregs).

nTregs comprise a subset of CD4 T cells that develop in the thymus and constitutively express cell surface IL- 2 receptor- $\alpha$ chain (CD25). $\mathrm{CD}^{+}{ }^{+} \mathrm{CD} 25^{+}$nTregs comprise approximately $10-20 \%$ of peripheral CD4 T cells in mice and in humans. nTregs are critical for maintaining self-tolerance, as disruption of thymic development or peripheral maintenance of these cells invariably results in the development of autoimmunity. A cluster of cell surface molecules besides CD25, such as cytotoxic T lymphocyte antigen-4 (CTLA-4), glucocorticoidinduced tumor-necrosis factor receptor family-related gene and lymphocyte activation antigen-3, have also been used to differentiate nTregs from conventional T cells. ${ }^{5}$ Transforming growth factor (TGF)$\beta$ is expressed in nTregs at high levels as a cell surface-bound form. ${ }^{6,7}$ nTregs suppress immune responses in an antigen-independent fashion in vitro and in vivo. ${ }^{5,8-10}$ Foxp3, an X-linked transcription factor belonging to the fork-head family, is specifically and highly expressed in nTregs. ${ }^{11}$ Thus, Foxp3 is currently used as the most reliable molecular marker for nTregs.

Conventional $\mathrm{T}$ cells are able to gain immunosuppressive activities and thus become iTregs. In the presence of exogenous TGF- $\beta$, naive CD4 T cells upregulate Foxp3 expression through de novo mechanisms and become immunosuppressive. ${ }^{12,13}$ Similar to nTregs,

Lineberger Comprehensive Cancer Center, Department of Microbiology and Immunology, The University of North Carolina at Chapel Hill, School of Medicine, North Carolina, NC, USA

Correspondence: YY Wan, Lineberger Comprehensive Cancer Center, CB 7295, 450 West Drive, Chapel Hill, NC 27599-7295, USA.

E-mail:wany@email.unc.edu

Received 17 January 2010; revised 2 March 2010; accepted 4 March 2010 
Foxp3-expressing iTregs also express higher levels of CD25. ${ }^{12}$ In addition, TGF- $\beta$ and IL-10 expression as well as secretion were found to be substantially upregulated in iTregs. iTregs not only are able to be generated in vitro but also can be induced in vivo. ${ }^{14}$ As a transcription factor specifically expressed in Tregs, Foxp3 has served as a surrogate marker for these cells. Therefore, to study the function and regulation of Tregs, different mouse models have been developed by various groups to mark the Foxp3-expressing $\mathrm{T}$ cells with fluorescent proteins-enhanced green fluorescent proteins (EGFP) or red fluorescent protein, through genetic manipulations. By purifying CD4 T cells which express these fluorescent markers, nTregs and iTregs generated in vivo can be isolated.

For the last decade, the research on Tregs has focused on their immunosuppressive function. The essential role of Tregs in immunosuppression is now indisputable. Yet the mechanisms by which Tregs carry out their function remain ill defined. Nevertheless, it is generally agreed that Tregs suppress immune responses through multiple mechanisms including cell contact-dependent and -independent mechanisms. Several surface molecules preferentially expressed by Tregs are proposed to be important for their function. For example, CD25, a high-affinity IL-2-binding receptor, is highly expressed by the $n$ Treg. The peripheral maintenance of nTregs appears to be dependent on IL-2 signaling, ${ }^{15-17}$ which is also important for the proliferation and survival of activated effector T cells. It is therefore hypothesized that one mechanism of nTreg suppression of conventional T-cell activation is through competition for IL-2 consumption. ${ }^{18-20}$ However, studies showing that CD25-deficient nTregs possess intact suppressive activity question the validity of this hypothesis. ${ }^{16}$ CTLA-4, another surface molecule preferentially expressed by nTregs, ${ }^{5}$ is important for inhibiting immune activation by competing for costimulatory receptor ligands expressed on innate cells $\mathrm{s}^{21}$ as well as inhibiting the function of antigen-presenting cells. ${ }^{22,23}$ Thus, it is suggested that CTLA-4 is important for nTreg-mediated immunosuppression. However, there is earlier genetic evidence against the critical roles for CTLA-4 in nTreg function, as the function of nTregs deficient in CTLA-4 appeared to be normal in vitro and in vivo. ${ }^{2,25}$ Antibodymediated blockage of CTLA- 4 was shown to abrogate nTreg function. It however remains unknown if this was due to a non-specific effect or a simultaneous blockage of CTLA-4 and its potential homolog(s) with redundant functions. Nevertheless, a recent study in which CTLA4 is specifically deleted in Tregs definitively showed that CTLA-4 expression in Tregs is critical in mediating Treg function. CTLA-4deficient Tregs lost suppressive activity and failed to prevent the onset of autoimmunity and systemic inflammation in vivo. ${ }^{26}$ Recent studies revealed unique roles for $\mathrm{T}$ helper (Th)-specifying factors in controlling Treg function and immune responses. When interferon (IFN) regulatory factor-4, a Th2-specifying factor, was specifically deleted in Tregs, enhanced Th2 immunity was observed. ${ }^{27}$ In addition, when STAT3, a factor important for Th17 differentiation, was specifically deleted in Tregs, enhanced Th17 immunity was observed. ${ }^{28}$ Moreover, T-bet, a Th1-specifying factor, was found to be upregulated in Tregs upon IFN- $\gamma$ stimulation. Such upregulation appeared to be important for the expression of CXCR3 and the survival of Tregs. ${ }^{29}$ This result thus suggests that Th-specifying factors are expressed by Tregs under certain conditions to promote immunosuppression in a manner specific to ongoing immune responses.

Cytokines also play important roles in nTreg function. TGF- $\beta$ appears to be critical in mediating nTreg function, as $\mathrm{T}$ cells from CD4-dnT $\beta$ RII mice that are unresponsive to TGF- $\beta$ are refractory to Treg-mediated suppression in vitro and in vivo. ${ }^{6,30,31}$ Despite the fact that TGF- $\beta$ mRNA is not elevated in nTregs, it is suggested that the membrane-bound form of TGF- $\beta$ is increased in nTregs and is important for their function. ${ }^{6,7}$ IL-10 is another immunosuppressive cytokine preferentially expressed in Tregs. ${ }^{32,33}$ and is important in mediating the functions of these cells. ${ }^{32,34}$ Besides suppressing effector T-cell function directly, Tregs dampen immune responses through regulating innate components, such as DCs. nTregs can potentially induce tolerogenic DCs through CTLA-4 engagement-induced tryptophan catabolism. ${ }^{35}$ In addition, it appears that Tregs destabilize the interaction between antigenic DCs and conventional T cells to prevent the activation of $\mathrm{T}$ cells. ${ }^{36}$ It is therefore clear now that multiple mechanisms are involved in Treg-mediated immunosuppression. Much work is needed in the future to identify cell contact-dependent and -independent mechanisms critical for controlling Treg function.

\section{DIVERSE FUNCTIONS OF Tregs BEYOND IMMUNOSUPPRESSION}

While we are still at the tip of the iceberg of understanding how Tregs control immunosuppression, emerging evidence suggests that Tregs are not only immunosuppressive but also able to become other types of effector Th cells to promote but not to suppress immune responses. To comprehend this idea, we will have to first clarify the definition of Tregs. Tregs have been traditionally defined by immunosuppressive activity since their discovery. However, because Foxp3 expression is accepted as a surrogate marker for identifying Treg lineage, Tregs have been redefined as Foxp3-expressing cells. Thus, Foxp3-expressing cells are now dubbed Treg lineage cells instead of functional immunosuppressing cells. By accepting this new definition, we start to realize that cells of Treg lineage, or Foxp3-expressing cells, play much more diverse roles than suppression in controlling immune responses. Before we explore the conversion of Tregs into other types of Th cells, we shall review what other types of Th cells have been identified and their characteristics, function and generation.

Th1 cells produce cytokine IFN- $\gamma$, TNF- $\alpha$ and TNF- $\beta$ to stimulate innate and T-cell immune responses. The prominent function for Th1 cells is to promote cell-mediated immunity characterized by cellular cytolytic activity. Th1 cells are important to protect the host from obligate intracellular pathogens, such as the protozoal parasite Leishmania major, ${ }^{37-39}$ the bacteria Mycobacterium avium ${ }^{40}$ and Salmonnella typhimurium ${ }^{41}$ as well as viruses herpes simplex virus, ${ }^{42}$ influenza A virus ${ }^{43}$ and vaccinia virus. ${ }^{44}$ Aberrant proinflammatory properties of Th1 cells can cause tissue damage and elicit unwanted inflammatory disease as well as self-reactivity including inflammatory bowel disease, ${ }^{45,46}$ graft-versus-host disease ${ }^{47}$ and autoimmune disorders, such as insulin-dependent diabetes mellitus ${ }^{48,49}$ and rheumatoid arthritis. ${ }^{50}$ IL-12 produced by activated innate immunity is a potent inducer for Th1 differentiation. ${ }^{51-54}$ Th1 differentiation and function are controlled through Th1-specific transcription factors. Tbet, also known as Tbx $21,{ }^{55}$ belongs to the T-box family of transcription factors and is the only known T-box gene specifically expressed in the lymphoid system. T-bet is rapidly and specifically induced in developing Th1 cells and is critically involved in initiating Th1 development, and thus, T-bet is recognized as a master regulator for Th1 differentiation. STAT4 is a transcription factor critical for IL-12 signaling and thus the full commitment of Th1 cells. ${ }^{56-58}$

Th2 cells are defined as producers of IL-4, IL-5, IL-9, IL-10 and IL13. The Th2 response is often associated with humoral responses and is important to resist extracellular pathogens, such as helminths and nematodes. ${ }^{59,60}$ Th2 cells are also important for mucosal immunity in the lung. An overstimulated Th2 response often leads to chronic 
inflammatory airway diseases, such as atopic asthma and allergy. ${ }^{61-67}$ IL-4 is the most prominent, if not the only, cytokine known to have the greatest influence in directing Th2 differentiation. ${ }^{68,69}$ The presence of IL-4, even if endogenously derived, is essential for Th2 differentiation. ${ }^{70-73}$ GATA3, a member of the GATA family of transcription factors, is sufficient and required for Th2 differentiation. ${ }^{74-76}$ Therefore, GATA3 is regarded as the master regulator for Th2 differentiation. STAT6 activated by IL-4 stimulation is the major signal transducer in IL-4-mediated Th2 differentiation. ${ }^{77,78}$ One of the mechanisms by which STAT6 promotes Th2 differentiation is through inducing high levels of transcription factor GATA3. ${ }^{79,80}$

Th17 cells are a newly identified class of effector T cell, which produces IL-17A and IL-17F. Th17 cells have been suggested to contribute to resistance to Listeria, Salmonella, Toxoplasma, Cryptococcus, Leishmania and Francisella. ${ }^{81-83}$ In addition to controlling infection, Th17 cells play a critical role in the induction and propagation of autoimmunity. IL-17 expression has been associated with autoimmune diseases such as multiple sclerosis, rheumatoid arthritis, psoriasis and inflammatory bowel disease as well as allergic responses. ${ }^{84,85}$ TGF- $\beta$ and IL- 6 act cooperatively and non-redundantly to promote Th17 commitment. ${ }^{86-88}$ IL-21, an IL-2 family member recently found to be highly produced by Th17 cells, can substitute for IL-6 to induce Th17 cells along with TGF- $\beta{ }^{89-91}$ Retinoic acidrelated orphan receptors (RORs) are the key transcription factors in Th17 differentiation. ROR- $\alpha$ and ROR- $\gamma$ t are both critical and somewhat redundant in promoting Th17 differentiation. ${ }^{92,93}$

Follicular helper T (Tfh) cells express high levels of CXCR5. B cellpromoting cytokines IL-10 and IL-21 are highly produced by Tfh cells, which are not typically associated with other types of Th cells. ${ }^{94-97}$ IL21 has been found to be critical for Tfh differentiation. ${ }^{95,97} \mathrm{Bcl}-6$ was recently reported to be a transcription factor that can be upregulated by IL-21 signaling and is critical for Tfh generation. ${ }^{98}$

\section{Plasticity of Tregs in vitro}

Treg to Th17 conversion. Under culture conditions, Treg to Th17 conversion has been extensively studied. The earlier observation that IL-6 was able to abrogate Treg-suppressive activity ${ }^{99}$ was intriguing. The activation of innate cells, such as DCs, was able to abrogate the suppressive function of Tregs. This effect was largely due to the secretion of proinflammatory cytokine IL- 6 by DCs because addition of exogenous IL-6 alone could abrogate Treg suppression. In addition, IL-6 production by the DCs is required for abolishing Treg suppressive activity, as IL-6 deficient DCs or antibody neutralization of IL-6 in the DC/T cell coculture restored Treg suppression. In the ensuing years, IL- 6 was found to be important to suppress Treg generation and to promote Th17 differentiation. TGF- $\beta$ promotes the generation of Foxp3-expressing Tregs. However, IL-6 antagonizes TGF- $\beta$ induced Treg generation and promotes Th17 differentiation. ${ }^{86,87}$ These reports further confirmed the notion that naive $\mathrm{T}$ cells can be directed into different types of effector $\mathrm{T}$ cells under different cytokine milieux. It nevertheless raises the possibility that Tregs may be able to convert into Th17 upon IL-6 stimulation due to the fact that TGF- $\beta$ is highly expressed by Tregs. Indeed, freshly isolated nTregs produced a large amount of TGF- $\beta$ upon stimulation in vitro. In the presence of IL-6, Foxp3-expressing cells expressed IL-17, suggesting that nTregs can be converted into Th17-like cells after commitment to the Treg program. ${ }^{100,101}$ Not only are nTregs able to be converted into Th17 cells, but also TGF- $\beta$-induced iTregs have been shown to turn into IL17-producing cells upon IL-6 stimulation. ${ }^{101}$ In these reports, Treg to Th17 conversion was concomitant with downregulation of Foxp3, whose expression has been shown to suppress ROR- $\gamma$ t expression and to shut down the Th17 program. ${ }^{100,102}$ Therefore, the downregulation of Foxp3 seems to be important to license Treg to Th17 differentiation. IL-6-dependent signaling is sufficient in both suppressing Foxp3 expression and promoting IL-17 expression. It is specifically required for the downregulation of Foxp3, as STAT3-deficient mice failed to repress Foxp 3 following IL-6 stimulation. Thus, IL-6 signaling appears to the molecular switch between Tregs and Th17. Note that, although IL-17 expression in Tregs coincides with Foxp3 downregulation, the total abolishment of Foxp3 is not required for Th17 conversion of Tregs because cells expressing both Foxp3 and IL-17 were found. ${ }^{100,101}$ Thus, Foxp3 expression and IL-17 expression are not mutually exclusive.

Treg conversion to other Th cells. Unlike Treg to Th17 conversion, few studies have addressed the potential of Foxp3-expressing cells to produce IFN- $\gamma$, and thus to undergo Th1 conversion in vitro, with somewhat controversial findings. In one study, Tregs were not found to be able to produce IFN- $\gamma$, even under Th1-polarizing conditions. ${ }^{101}$ However, in the other study, Foxp3-expressing cells were found to produce IFN- $\gamma$ under Th1 conditions in Foxp3-expressing and Foxp3-non-expressing populations ${ }^{103,104}$ (our unpublished observation). Such discrepancy in the results could be due to different experimental conditions. Without addition of a large amount of exogenous IL-2, Foxp3-expressing cells display an anergic phenotype and can not be activated. This might account for the lack of cytokine production observed in the first report. However, when a high dose of exogenous IL-2 is provided in the culture to force Tregs to exit the anergic state, as described in the second report, Tregs generate substantial amounts of IFN- $\gamma$ to become Th1 cells ${ }^{103,104}$ (our unpublished observation). These findings suggest that Tregs are able to convert into Th1 cells in vitro under certain conditions. While Tregs possess great plasticity to convert into Th1 and Th17 cells, no evidence has been presented to show that nTregs can be converted into Th2 cells under culture conditions. When CD4 T cells were stimulated in the presence of IL- 4 and TGF- $\beta$, TGF- $\beta$-induced Foxp3 expression was decreased. ${ }^{105}$ However, activated $\mathrm{T}$ cells did not become IL-4producing $\mathrm{T}$ cells. Instead, they produced IL-9. ${ }^{106,107}$ Therefore, whether Tregs are able to become IL-4-producing cells in vitro remains unknown.

\section{Plasticity of Tregs in vivo}

The aforementioned studies' efforts were devoted to investigating cytokine-driven conversion of Tregs. Most of these studies focused on converting TGF- $\beta$-induced iTregs into other types of Th cells under culture conditions. One of the important questions is whether Tregs can be converted into other types of Th cells under physiological conditions. In addition, if such conversions indeed occur in vivo, what might be the biological significance of such a conversion?

Accumulating evidence has been presented to show that Tregs can convert into effector T cells in vivo. When an EGFP expression cassette was knocked into the first exon of the endogenous foxp 3 gene, cells that lacked functional Foxp 3 protein but had active Foxp 3 promoter activities were thus marked with green fluorescence protein (GFP). In such a mouse model, loss of functional Foxp3 resulted in a Scurfy-like phenotype in the mice. However, in these mice, GFP-expressing cells were readily detected and were at an elevated percentage compared to that in the healthy mice. These GFP-expressing cells bore Treg signatures at reduced levels. Although these cells could not suppress the immune response, they were anergic to T-cell receptor stimulation. 
Thus, these cells were Treg lineage but with abrogated immunosuppressive function. These Tregs were shown to become effector T cells in vivo by producing IFN- $\gamma$, IL-4 and IL-17. Therefore, with the loss of Foxp 3 expression, Tregs could be generated but functionally dysregulated by losing suppressive activity and gaining Th1, Th2 and Th17 effector function. ${ }^{108}$ Without artificially ablating Foxp3 function, Tregs were also shown to downregulate Foxp3 expression and convert into effector $\mathrm{T}$ cells in vivo. In one study, Zhou et al. generated a bacterial artificial chromosome transgenic mouse model where Cre and EGFP were expressed in Foxp3-expressing Tregs ${ }^{109}$. By crossing such a mouse with a yellow fluorescent protein (YFP) Cre-reporter mouse strain, they tracked all the $\mathrm{T}$ cells that were currently expressing and had previously expressed Foxp3. They found that, in vivo, a small percentage of CD4 T cells expressed YFP but not GFP, indicating that these $\mathrm{T}$ cells used to express Foxp3 but had shut down the Foxp3 expression at the time of assay. Therefore, downregulation of Foxp3 expression in Tregs normally occurs in vivo. They referred to these YFP positive and GFP negative cells as exFoxp3 Tregs. In addition, they found that exFoxp3 Tregs expressed IFN- $\gamma$ and IL-17, suggesting their conversion into Th1 and Th17 cells. Moreover, exFoxp3 Tregs are able to promote inflammation and to contribute to the onset of type 1 diabetes upon transfer. Therefore, Treg to Th conversion could be important for directing inflammatory responses. Following transfer into the recipients, exFoxp3 Tregs were not able to regain Foxp3 expression, suggesting that conversion of Treg into Th cells is an irreversible process. ${ }^{109}$ Th1 conversion of Tregs was also reported during lethal parasitic infection. ${ }^{110}$ When mice were infected with a lethal dose of Toxoplasma gondii, Foxp3-expressing Tregs became IFN- $\gamma$-producing Th1 cells. Interestingly, a decrease of Foxp 3 expression was not associated with Treg to Th1 conversion in this study. Evidence for Treg to Tfh conversion in vivo is also available. Upon transfer into $\mathrm{CD} 3^{-1-}$ mice where $\mathrm{T}$ cells were absent, Foxp3expressing Tregs downregulate Foxp3 expression in Peyer's patches. The transferred Foxp3-non-expressing Tregs but not Foxp3expressing Tregs clustered around germinal centers, expressing CXCR5, IL21 and Bcl6, a phenotype resembling Tfh. ${ }^{111}$

In the studies mentioned above, Treg to Th conversion invariantly concurred with the loss of Foxp3 expression, suggesting that conversion and Foxp3 expression might be mutually exclusive, and questioning the intrinsic ability of Tregs to become other types of Th cells in vivo. By knocking a luciferase and EGFP-expressing cassette into the $3^{\prime}$-untranslated region of the endogenous Foxp3 gene locus, we serendipitously generated a mouse model whose Tregs expressed Foxp3 but with reduced levels. ${ }^{112}$ Reduction of Foxp3 expression resulted in a systemic autoimmune syndrome similar to what has been observed in Scurfy mice. Further analysis revealed that Foxp3-expressing T cells were generated in these mice, but without suppressive activities, although they remained anergic to $\mathrm{T}$-cell receptor stimulation. Interestingly, reduction of Foxp3 led to a preferential conversion of Tregs into IL-4-producing Th2 cells. ${ }^{112} \mathrm{Th} 2$ conversion of Tregs might be essential for directing Th2 responses, as reduced Foxp3 expression in Tregs has been associated with Th2-type immune disorders in different mouse models. Thus, in vivo, Foxp3 expression and Treg to Th conversion are not mutually exclusive. Additionally, the expression of Foxp3 seems to limit the potential of Tregs to be converted into all types of Th cells. Whether Tregs with reduced Foxp3 expression are able to convert into other types of Th cells remains to be addressed. More importantly, it appears that the expression levels of Foxp3 control Treg function: high levels of Foxp3 expression endow T cells with suppressive activity; reduced levels lead to Th2 conversion and loss of
Foxp3 licenses Tregs to Th1, Th2, Th17 and Tfh conversion. Thus, Foxp3 serves as a rheostat controlling the diverse function of Tregs in vivo. The mechanisms underlying such phenomena are important questions deserving to be addressed in the future. In addition, as Foxp3 downregulation is a critical trigger for Treg to Th conversion in vivo, what triggers Foxp3 downregulation, or alternatively, what maintains high levels of Foxp3 expression, are questions that need to be addressed. Furthermore, the biological functions of Treg conversion during normal and aberrant immune responses still wait to be revealed.

While the signal transduction network controlling Treg to Th conversion waits to be unveiled, studies on epigenetic control of Treg and Th differentiation have provided important mechanistic insights. Tlineage specification is accompanied by epigenetic modifications of key cytokine and transcription factor gene loci. Such epigenetic change provides a basis for the heritability of gene expression patterns acquired by differentiating T cells. ${ }^{13,114}$ Histone methylation or acetylation, DNA methylation and higher order chromatin structure each contribute to regulation of the accessibility of cis elements that bind lineage-specifying transcription factors and ultimately the expression of lineage-specific genes. The growing recognition of instability in the functional T-cell repertoire, as demonstrated in particular by plasticity of Treg programs, implies greater malleability in T-cell epigenetic modifications than previously thought, and suggests that conversion of Tregs is likely reflected in the reversal of epigenetic modifications induced during initial differentiation of these cells.

A global genome analysis of permissive and repressive histone methylation marks of naive, Th1, Th2, Th17 cells, nTregs and iTregs was recently reported, providing a mechanistic basis for aspects of Treg conversion. ${ }^{104}$ Trimethylations of histone H3 were identified at the proximal promoters of key T-lineage transcription factors or cytokine genes. H3K4me3 and H3K27me3 were used to mark the genes that are expressed or repressed, respectively. The promoters for the genes highly expressed in certain Th lineages correlated with permissive $\mathrm{H} 3 \mathrm{~K} 4 \mathrm{me} 3$ configuration. However, the promoters for the genes not expressed were not necessarily associated with high amounts of repressive $\mathrm{H} 3 \mathrm{~K} 27 \mathrm{me} 3$ configuration. While only a small number of lineage-specific $\mathrm{H} 3$-methylation islands were found for Th cells, a large number of the unique $\mathrm{H} 3 \mathrm{~K} 4 \mathrm{me} 3$ and $\mathrm{H} 3 \mathrm{~K} 27 \mathrm{me} 3$ islands were found in nTregs, underlying their greater potential for diverse functions. Indeed, although the promoters for IFN- $\gamma$, IL-4 and IL-17A were not marked with $\mathrm{H} 3 \mathrm{~K} 4 \mathrm{me} 3$ for active expression, they were not marked with $\mathrm{H} 3 \mathrm{~K} 27 \mathrm{me} 3$ for active suppression either. In addition, transcription factors T-bet, GATA3 and ROR- $\gamma$ t that master Th1, Th2 and Th17 differentiation, respectively, were not marked with the suppressive configuration in Tregs. Thus, at the epigenetic level, Tregs did not shut down the genetic program for other Th cells and remained permissive for their differentiation. ${ }^{104}$

\section{FINAL REMARKS}

Being initially identified as suppressor T cells, Foxp3-expressing cells are critical in maintaining self-tolerance and immune homeostasis. With collective efforts over many years, we have achieved tremendous progress in understanding the immunological function of Tregs as well as how this type of T cells is regulated during normal and pathological immune responses. Recently, evidence has suggested that immunosuppression might not be the only function of Foxp3-expressing cells. They may convert into proinflammatory cells to promote immune responses. Such findings have important biological implications, as T-cell receptors of Tregs tend to be modestly self-reactive. The 
aberrant function of Tregs and Treg to Th conversion could be critical in instigating and directing unwanted immunopathologies. Therefore, understanding how Treg to Th conversion occurs should enhance our understanding of the etiology of autoimmunity and inflammatory diseases. By generating reporter mice for Tregs and different subtypes of Th cells, we have started to unravel the diverse function of Tregs in vitro and in vivo. Future studies to investigate the molecular mechanisms of Treg to Th conversion and to address what impact such converted Tregs might have on various immune disorders are warranted.

\section{ACKNOWLEDGEMENTS}

Y. Y. Wan is supported by a K99/R00 award from NIH/NIAID. We are grateful to R. Zhai for critical reading of the manuscript and helpful comments.

1 Gershon RK. A disquisition on suppressor T cells. Transplant Rev 1975; 26: 170-185.

2 Gershon RK, Kondo K. Cell interactions in the induction of tolerance: the role of thymic lymphocytes. Immunology 1970; 18: 723-737.

3 Gershon RK, Kondo K. Infectious immunological tolerance. Immunology 1971; 21: 903-914.

4 Sakaguchi S, Sakaguchi N, Asano M, Itoh M, Toda M. Immunologic self-tolerance maintained by activated T cells expressing IL-2 receptor alpha-chains (CD25). Breakdown of a single mechanism of self-tolerance causes various autoimmune diseases. J Immunol 1995; 155: 1151-1164.

5 Sakaguchi S. Naturally arising $\mathrm{CD}^{+}$regulatory T cells for immunologic self-tolerance and negative control of immune responses. Annu Rev Immunol 2004; 22: 531-562.

6 Green EA, Gorelik L, McGregor CM, Tran EH, Flavell RA. CD $4^{+} \mathrm{CD} 25^{+}$T regulatory cells control anti-islet CD8 ${ }^{+} \mathrm{T}$ cells through TGF-beta-TGF-beta receptor interactions in type 1 diabetes. Proc Natl Acad Sci USA 2003; 100: 10878-10883.

7 Nakamura K, Kitani A, Strober W. Cell contact-dependent immunosuppression by $\mathrm{CD} 4{ }^{+} \mathrm{CD} 25^{+}$regulatory $\mathrm{T}$ cells is mediated by cell surface-bound transforming growth factor beta. J Exp Med 2001; 194: 629-644.

8 Sakaguchi S. Naturally arising Foxp3-expressing $\mathrm{CD} 25^{+} \mathrm{CD} 4^{+}$regulatory T cells in immunological tolerance to self and non-self. Nat Immunol 2005; 6: 345-352.

9 Shevach EM. Regulatory T cells in autoimmmunity*. Annu Rev Immunol 2000; 18: 423-449.

10 Shevach EM. CD4 ${ }^{+} \mathrm{CD} 25^{+}$suppressor T cells: more questions than answers. Nat Rev Immunol 2002; 2: 389-400.

11 Fontenot JD, Gavin MA, Rudensky AY. Foxp3 programs the development and function of $\mathrm{CD}^{+}{ }^{+} \mathrm{CD} 25^{+}$regulatory T cells. Nat Immunol 2003; 4: 330-336.

12 Chen W, Jin W, Hardegen N, Lei KJ, Li L, Marinos N et al. Conversion of peripheral $\mathrm{CD} 4^{+} \mathrm{CD} 25^{-}$naive $\mathrm{T}$ cells to $\mathrm{CD} 4^{+} \mathrm{CD} 25^{+}$regulatory $\mathrm{T}$ cells by TGF-beta induction of transcription factor Foxp3. J Exp Med 2003; 198: 1875-1886.

13 Wan YY, Flavell RA. Identifying Foxp3-expressing suppressor T cells with a bicistronic reporter. Proc Natl Acad Sci USA 2005; 102: 5126-5131.

14 Kretschmer K, Apostolou I, Hawiger D, Khazaie K, Nussenzweig MC, von Boehmer H. Inducing and expanding regulatory $\mathrm{T}$ cell populations by foreign antigen. Nat Immunol 2005; 6: 1219-1227.

15 D'Cruz LM, Klein L. Development and function of agonist-induced CD25 $5^{+}$Foxp3 ${ }^{+}$ regulatory T cells in the absence of interleukin 2 signaling. Nat Immunol 2005; 6: 1152-1159.

16 Fontenot JD, Rasmussen JP, Gavin MA, Rudensky AY. A function for interleukin 2 in Foxp3-expressing regulatory T cells. Nat Immunol 2005; 6: 1142-1151.

17 Furtado GC, Curotto de Lafaille MA, Kutchukhidze N, Lafaille JJ. Interleukin 2 signaling is required for $\mathrm{CD}^{+}{ }^{+}$regulatory T cell function. J Exp Med 2002; 196 : 851-857.

18 Barthlott T, Moncrieffe H, Veldhoen M, Atkins CJ, Christensen J, O'Garra A et al. $\mathrm{CD}^{2} 5^{+} \mathrm{CD} 4^{+} \mathrm{T}$ cells compete with naive $\mathrm{CD} 4^{+} \mathrm{T}$ cells for IL-2 and exploit it for the induction of IL-10 production. Int Immunol 2005; 17: 279-288.

19 de la Rosa M, Rutz S, Dorninger H, Scheffold A. Interleukin-2 is essential for $\mathrm{CD} 4{ }^{+} \mathrm{CD} 25^{+}$regulatory T cell function. Eur J Immunol 2004; 34: 2480-2488.

20 Pandiyan $\mathrm{P}$, Zheng L, Ishihara S, Reed J, Lenardo MJ. CD4 ${ }^{+} \mathrm{CD} 25^{+}$Foxp $3^{+}$regulatory $\mathrm{T}$ cells induce cytokine deprivation-mediated apoptosis of effector $\mathrm{CD}^{+} \mathrm{T}$ cells. Nat Immunol 2007; 8: 1353-1362.

21 Egen JG, Allison JP. Cytotoxic T lymphocyte antigen-4 accumulation in the immunological synapse is regulated by TCR signal strength. Immunity 2002; 16: 23-35.

22 Greenwald RJ, Freeman GJ, Sharpe AH. The B7 family revisited. Annu Rev Immunol 2005; 23: 515-548.

23 Slavik JM, Hutchcroft JE, Bierer BE. CD28/CTLA-4 and CD80/CD86 families: signaling and function. Immunol Res 1999; 19: 1-24.

24 Boden E, Tang Q, Bour-Jordan H, Bluestone JA. The role of CD28 and CTLA4 in the function and homeostasis of $\mathrm{CD}^{+}{ }^{+} \mathrm{CD} 25^{+}$regulatory T cells. Novartis Found Symp 2003; 252: 55-63; discussion 63-56, 106-114.
25 Read S, Greenwald R, Izcue A, Robinson N, Mandelbrot D, Francisco L et al. Blockade of CTLA-4 on $\mathrm{CD} 4{ }^{+} \mathrm{CD} 25^{+}$regulatory $\mathrm{T}$ cells abrogates their function in vivo. $\mathrm{J}$ Immunol 2006; 177: 4376-4383.

26 Wing K, Onishi Y, Prieto-Martin P, Yamaguchi T, Miyara M, Fehervari Z et al. CTLA-4 control over Foxp3 ${ }^{+}$regulatory T cell function. Science 2008; 322: 271-275.

27 Zheng Y, Chaudhry A, Kas A, deRoos P, Kim JM, Chu TT et al. Regulatory T-cell suppressor program co-opts transcription factor IRF4 to control $\mathrm{T}(\mathrm{H}) 2$ responses. Nature 2009; 458: 351-356.

28 Chaudhry A, Rudra D, Treuting P, Samstein RM, Liang Y, Kas A et al. CD4 ${ }^{+}$regulatory T cells control TH17 responses in a Stat3-dependent manner. Science 2009; 326: 986-991.

29 Koch MA, Tucker-Heard G, Perdue NR, Killebrew JR, Urdahl KB, Campbell DJ. The transcription factor $T$-bet controls regulatory $T$ cell homeostasis and function during type 1 inflammation. Nat Immunol 2009; 10: 595-602.

30 Chen ML, Pittet MJ, Gorelik L, Flavell RA, Weissleder R, von Boehmer $\mathrm{H}$ et al. Regulatory $\mathrm{T}$ cells suppress tumor-specific CD8 T cell cytotoxicity through TGF-beta signals in vivo. Proc Natl Acad Sci USA 2005; 102: 419-424.

31 Fahlen L, Read S, Gorelik L, Hurst SD, Coffman RL, Flavell RA et al. T cells that cannot respond to TGF-beta escape control by $\mathrm{CD} 4^{+} \mathrm{CD} 25^{+}$regulatory T cells. J Exp Med 2005; 201: 737-746.

32 Kamanaka M, Kim ST, Wan YY, Sutterwala FS, Lara-Tejero M, Galan JE et al. Expression of interleukin-10 in intestinal lymphocytes detected by an interleukin10 reporter knockin tiger mouse. Immunity 2006; 25: 941-952.

33 Uhlig HH, Coombes J, Mottet C, Izcue A, Thompson C, Fanger A et al. Characterization of Foxp $3^{+} \mathrm{CD} 4^{+} \mathrm{CD} 25^{+}$and IL-10-secreting $\mathrm{CD} 4^{+} \mathrm{CD} 25^{+} \mathrm{T}$ cells during cure of colitis. J Immunol 2006; 177: 5852-5860.

34 Asseman C, Mauze S, Leach MW, Coffman RL, Powrie F. An essential role for interleukin 10 in the function of regulatory $T$ cells that inhibit intestinal inflammation. J Exp Med 1999; 190: 995-1004.

35 Fallarino F, Grohmann U, Hwang KW, Orabona C, Vacca C, Bianchi R et al. Modulation of tryptophan catabolism by regulatory T cells. Nat Immunol 2003; 4: 1206-1212.

36 Tadokoro CE, Shakhar G, Shen S, Ding Y, Lino AC, Maraver A et al. Regulatory T cells inhibit stable contacts between $\mathrm{CD} 4^{+} \mathrm{T}$ cells and dendritic cells in vivo. J Exp Med 2006; 203: 505-511.

37 Heinzel FP, Sadick MD, Holaday BJ, Coffman RL, Locksley RM. Reciprocal expression of interferon gamma or interleukin 4 during the resolution or progression of murine leishmaniasis. Evidence for expansion of distinct helper T cell subsets. J Exp Med 1989; 169: 59-72.

38 Sadick MD, Heinzel FP, Shigekane VM, Fisher WL, Locksley RM. Cellular and humoral immunity to Leishmania major in genetically susceptible mice after in vivo depletion of L3T4 ${ }^{+}$T cells. J Immunol 1987; 139: 1303-1309.

39 Scott P, Natovitz P, Coffman RL, Pearce E, Sher A. Immunoregulation of cutaneous leishmaniasis. $T$ cell lines that transfer protective immunity or exacerbation belong to different T helper subsets and respond to distinct parasite antigens. J Exp Med 1988; 168: 1675-1684.

40 Kobayashi K, Nakata N, Kai M, Kasama T, Hanyuda Y, Hatano Y. Decreased expression of cytokines that induce type 1 helper $\mathrm{T}$ cell/interferon-gamma responses in genetically susceptible mice infected with Mycobacterium avium. Clin Immunol Immunopathol 1997; 85: 112-116.

41 Mastroeni P, Clare S, Khan S, Harrison JA, Hormaeche CE, Okamura $\mathrm{H}$ et al. Interleukin 18 contributes to host resistance and gamma interferon production in mice infected with virulent Salmonella typhimurium. Infect Immun 1999; 67: 478-483.

42 Fujioka N, Akazawa R, Ohashi K, Fujii M, Ikeda M, Kurimoto M. Interleukin-18 protects mice against acute herpes simplex virus type 1 infection. J Virol 1999; 73: 2401-2409.

43 Sareneva T, Matikainen S, Kurimoto M, Julkunen I. Influenza A virus-induced IFNalpha/beta and IL-18 synergistically enhance IFN-gamma gene expression in human $T$ cells. J Immunol 1998; 160: 6032-6038.

44 Tanaka-Kataoka M, Kunikata T, Takayama S, Iwaki K, Ohashi K, Ikeda M et al. In vivo antiviral effect of interleukin 18 in a mouse model of vaccinia virus infection. Cytokine 1999; 11: 593-599.

45 Davidson NJ, Leach MW, Fort MM, Thompson-Snipes L, Kuhn R, Muller W et al. T helper cell 1-type $\mathrm{CD}^{+}{ }^{+} \mathrm{T}$ cells, but not B cells, mediate colitis in interleukin 10deficient mice. J Exp Med 1996; 184: 241-251.

46 Parronchi P, Romagnani P, Annunziato F, Sampognaro S, Becchio A, Giannarini L et al. Type 1 T-helper cell predominance and interleukin- 12 expression in the gut of patients with Crohn's disease. Am J Pathol 1997; 150: 823-832.

$47 \mathrm{Hu} \mathrm{HZ}$, Li GL, Lim YK, Chan SH, Yap EH. Kinetics of interferon-gamma secretion and its regulatory factors in the early phase of acute graft-versus-host disease. Immunology 1999; 98: 379-385.

48 Pakala SV, Chivetta M, Kelly CB, Katz JD. In autoimmune diabetes the transition from benign to pernicious insulitis requires an islet cell response to tumor necrosis factor alpha. J Exp Med 1999; 189: 1053-1062.

49 Wang B, Andre I, Gonzalez A, Katz JD, Aguet M, Benoist C et al. Interferon-gamma impacts at multiple points during the progression of autoimmune diabetes. Proc NatI Acad Sci USA 1997; 94: 13844-13849.

50 Leung BP, McInnes IB, Esfandiari E, Wei XQ, Liew FY. Combined effects of IL-12 and IL-18 on the induction of collagen-induced arthritis. J Immunol 2000; 164: 6495-6502

51 Hsieh CS, Macatonia SE, Tripp CS, Wolf SF, O'Garra A, Murphy KM. Development of $\mathrm{TH} 1 \mathrm{CD}^{+}{ }^{+} \mathrm{T}$ cells through IL-12 produced by Listeria-induced macrophages. Science 1993; 260: 547-549. 
52 Manetti R, Gerosa F, Giudizi MG, Biagiotti R, Parronchi P, Piccinni MP et al. Interleukin 12 induces stable priming for interferon gamma (IFN-gamma) production during differentiation of human T helper (Th) cells and transient IFN-gamma production in established Th2 cell clones. J Exp Med 1994; 179: 1273-1283.

53 Manetti R, Parronchi P, Giudizi MG, Piccinni MP, Maggi E, Trinchieri G et al. Natura killer cell stimulatory factor (interleukin 12 [IL-12]) induces T helper type 1 (Th1) specific immune responses and inhibits the development of IL-4-producing Th cells. J Exp Med 1993; 177: 1199-1204.

54 Seder RA, Gazzinelli R, Sher A, Paul WE. Interleukin 12 acts directly on CD4 ${ }^{+}$T cells to enhance priming for interferon gamma production and diminishes interleukin 4 inhibition of such priming. Proc Natl Acad Sci USA 1993; 90: 10188-10192.

55 Szabo SJ, Kim ST, Costa GL, Zhang X, Fathman CG, Glimcher LH. A novel transcription factor, T-bet, directs Th1 lineage commitment. Cell 2000; 100: 655-669.

56 Kaplan MH, Sun YL, Hoey T, Grusby MJ. Impaired IL-12 responses and enhanced development of Th2 cells in Stat4-deficient mice. Nature 1996; 382: 174-177.

57 Ouyang W, Jacobson NG, Bhattacharya D, Gorham JD, Fenoglio D, Sha WC et al. The Ets transcription factor ERM is Th1-specific and induced by IL-12 through a Stat4dependent pathway. Proc Natl Acad Sci USA 1999; 96: 3888-3893.

58 Yang J, Murphy TL, Ouyang W, Murphy KM. Induction of interferon-gamma production in Th1 CD4 ${ }^{+}$T cells: evidence for two distinct pathways for promoter activation. Eur Immunol 1999; 29: 548-555.

59 Finkelman FD, Pearce EJ, Urban JF Jr, Sher A. Regulation and biological function of helminth-induced cytokine responses. Immunol Today 1991; 12: A62-66.

60 Sher A, Coffman RL. Regulation of immunity to parasites by T cells and T cell-derived cytokines. Annu Rev Immunol 1992; 10: 385-409.

61 Durham SR, Ying S, Varney VA, Jacobson MR, Sudderick RM, Mackay IS et al. Cytokine messenger RNA expression for IL-3, IL-4, IL-5, and granulocyte/ macrophage-colony-stimulating factor in the nasal mucosa after local allergen provocation: relationship to tissue eosinophilia. J Immunol 1992; 148: 2390-2394.

62 Ebner C, Szepfalusi Z, Ferreira F, Jilek A, Valenta R, Parronchi P et al. Identification of multiple T cell epitopes on Bet $\mathrm{v} I$, the major birch pollen allergen, using specific $T$ cell clones and overlapping peptides. J Immunol 1993; 150: 1047-1054.

63 Kay AB, Ying S, Varney V, Gaga M, Durham SR, Moqbel R et al. Messenger RNA expression of the cytokine gene cluster, interleukin 3 (IL-3), IL-4, IL-5, and granulocyte/macrophage colony-stimulating factor, in allergen-induced late-phase cutaneous reactions in atopic subjects. J Exp Med 1991; 173: 775-778.

64 Parronchi P, Macchia D, Piccinni MP, Biswas P, Simonelli C, Maggi E et al. Allergenand bacterial antigen-specific T-cell clones established from atopic donors show different profile of cytokine production. Proc Natl Acad Sci USA 1991; 88 4538-4542.

65 Robinson DS, Hamid Q, Ying S, Tsicopoulos A, Barkans J, Bentley AM et al. Predominant TH2-like bronchoalveolar T-lymphocyte population in atopic asthma. N Engl J Med 1992; 326: 298-304.

66 Wierenga EA, Snoek M, de Groot C, Chretien I, Bos JD, Jansen HM et al. Evidence for compartmentalization of functional subsets of $\mathrm{CD} 2^{+} \mathrm{T}$ lymphocytes in atopic patients. J Immunol 1990; 144: 4651-4656.

67 Yssel H, Johnson KE, Schneider PV, Wideman J, Terr A, Kastelein R et al. T cell activation-inducing epitopes of the house dust mite allergen Der $\mathrm{p}$ I. Proliferation and lymphokine production patterns by Der $\mathrm{p} \mathrm{I-specific} \mathrm{CD} 4^{+} \mathrm{T}$ cell clones. $J$ Immunol 1992; 148: 738-745.

68 Le Gros G, Ben-Sasson SZ, Seder R, Finkelman FD, Paul WE. Generation of interleukin 4 (IL-4)-producing cells in vivo and in vitro: IL-2 and IL-4 are required for in vitro generation of IL-4-producing cells. J Exp Med 1990; 172: 921-929.

69 Swain SL, Weinberg AD, English M, Huston G. IL-4 directs the development of Th2 like helper effectors. J Immunol 1990; 145: 3796-3806.

70 Grunewald SM, Werthmann A, Schnarr B, Klein CE, Brocker EB, Mohrs M et al. A antagonistic IL-4 mutant prevents type I allergy in the mouse: inhibition of the IL-4/IL13 receptor system completely abrogates humoral immune response to allergen and development of allergic symptoms in vivo. J Immunol 1998; 160: 4004-4009.

71 Kuhn R, Rajewsky K, Muller W. Generation and analysis of interleukin-4 deficient mice. Science 1991; 254: 707-710.

72 Kurup VP, Choi HY, Murali PS, Xia JQ, Coffman RL, Fink JN. Immune responses to Aspergillus antigen in IL-4 $4^{-/}$mice and the effect of eosinophil ablation. Allergy 1999; 54: $420-427$.

73 Urban JF Jr, Noben-Trauth N, Donaldson DD, Madden KB, Morris SC, Collins M et al. IL-13, IL-4Ralpha, and Stat6 are required for the expulsion of the gastrointestinal nematode parasite Nippostrongylus brasiliensis. Immunity 1998; 8: 255-264.

74 Ouyang W, Ranganath SH, Weindel K, Bhattacharya D, Murphy TL, Sha WC et al. Inhibition of Th1 development mediated by GATA-3 through an IL-4-independent mechanism. Immunity 1998; 9: 745-755.

75 Pai SY, Truitt ML, Ho IC. GATA-3 deficiency abrogates the development and maintenance of T helper type 2 cells. Proc Natl Acad Sci USA 2004; 101: 1993-1998.

76 Zhu J, Min B, Hu-Li J, Watson CJ, Grinberg A, Wang Q et al. Conditional deletion of Gata3 shows its essential function in $\mathrm{T}(\mathrm{H}) 1-\mathrm{T}(\mathrm{H}) 2$ responses. Nat Immunol 2004; 5 1157-1165.

77 Shimoda K, van Deursen J, Sangster MY, Sarawar SR, Carson RT, Tripp RA et al. Lack of IL-4-induced Th2 response and IgE class switching in mice with disrupted Stat6 gene. Nature 1996; 380: 630-633.

78 Takeda K, Tanaka T, Shi W, Matsumoto M, Minami M, Kashiwamura S et al. Essential role of Stat6 in IL-4 signalling. Nature 1996; 380: 627-630.

79 Kurata H, Lee HJ, O'Garra A, Arai N. Ectopic expression of activated Stat6 induces the expression of Th2-specific cytokines and transcription factors in developing Th1 cells. Immunity 1999; 11: 677-688.
80 Zhu J, Guo L, Watson CJ, Hu-Li J, Paul WE. Stat6 is necessary and sufficient for IL-4's role in Th2 differentiation and cell expansion. J Immunol 2001; 166: 7276-7281.

81 Chackerian AA, Chen SJ, Brodie SJ, Mattson JD, McClanahan TK, Kastelein RA et al. Neutralization or absence of the interleukin-23 pathway does not compromise immunity to mycobacterial infection. Infect Immun 2006; 74: 6092-6099.

82 Kleinschek MA, Muller U, Brodie SJ, Stenzel W, Kohler G, Blumenschein WM et al. IL23 enhances the inflammatory cell response in Cryptococcus neoformans infection and induces a cytokine pattern distinct from IL-12. J Immunol 2006; 176 1098-1106.

83 Lieberman LA, Cardillo F, Owyang AM, Rennick DM, Cua DJ, Kastelein RA et al. IL-23 provides a limited mechanism of resistance to acute toxoplasmosis in the absence of IL-12. J Immunol 2004; 173: 1887-1893.

84 Langrish CL, Chen Y, Blumenschein WM, Mattson J, Basham B, Sedgwick JD et al. IL 23 drives a pathogenic $T$ cell population that induces autoimmune inflammation. J Exp Med 2005; 201: 233-240.

85 Yen D, Cheung J, Scheerens H, Poulet F, McClanahan T, McKenzie B et al. IL-23 is essential for T cell-mediated colitis and promotes inflammation via IL-17 and IL-6. J Clin Invest 2006; 116: 1310-1316.

86 Bettelli E, Carrier Y, Gao W, Korn T, Strom TB, Oukka M et al. Reciprocal developmental pathways for the generation of pathogenic effector TH17 and regulatory T cells. Nature 2006; 441: 235-238.

87 Mangan PR, Harrington LE, O'Quinn DB, Helms WS, Bullard DC, Elson CO et al. Transforming growth factor-beta induces development of the $T(H) 17$ lineage. Nature 2006; 441: 231-234.

88 Veldhoen M, Hocking RJ, Atkins CJ, Locksley RM, Stockinger B. TGFbeta in the context of an inflammatory cytokine milieu supports de novo differentiation of IL17-producing T cells. Immunity 2006; 24: 179-189.

89 Korn T, Bettelli E, Gao W, Awasthi A, Jager A, Strom TB et al. IL-21 initiates an alternative pathway to induce proinflammatory $\mathrm{T}(\mathrm{H}) 17$ cells. Nature 2007; 448: 484-487

90 Nurieva R, Yang XO, Martinez G, Zhang Y, Panopoulos AD, Ma L et al. Essentia autocrine regulation by IL-21 in the generation of inflammatory T cells. Nature 2007; 448: 480-483.

91 Zhou L, Ivanov, II, Spolski R, Min R, Shenderov K, Egawa T et al. IL-6 programs T(H)17 cell differentiation by promoting sequential engagement of the IL-21 and IL-23 pathways. Nat Immunol 2007; 8: 967-974.

92 Ivanov, II, McKenzie BS, Zhou L, Tadokoro CE, Lepelley A, Lafaille JJ et al. The orphan nuclear receptor RORgammat directs the differentiation program of proinflammatory IL-17 ${ }^{+}$T helper cells. Cell 2006; 126: 1121-1133.

93 Yang XO, Pappu BP, Nurieva R, Akimzhanov A, Kang HS, Chung Y et al. T helper 17 lineage differentiation is programmed by orphan nuclear receptors ROR alpha and ROR gamma. Immunity 2008; 28: 29-39.

94 Chtanova T, Tangye SG, Newton R, Frank N, Hodge MR, Rolph MS et al. T follicular helper cells express a distinctive transcriptional profile, reflecting their role as nonTh1/Th2 effector cells that provide help for B cells. J Immunol 2004; 173: 68-78.

95 Nurieva RI, Chung Y, Hwang D, Yang XO, Kang HS, Ma L et al. Generation of T follicular helper cells is mediated by interleukin-21 but independent of Thelper 1, 2, or 17 cell lineages. Immunity 2008; 29: 138-149.

96 Suto A, Kashiwakuma D, Kagami S, Hirose K, Watanabe N, Yokote $\mathrm{K}$ et al Development and characterization of $\mathrm{IL}-21$-producing $\mathrm{CD}^{+}{ }^{+} \mathrm{T}$ cells. J Exp Med 2008; 205: 1369-1379.

97 Vogelzang A, McGuire HM, Yu D, Sprent J, Mackay CR, King C. A fundamental role for interleukin-21 in the generation of T follicular helper cells. Immunity 2008; 29: 127-137.

98 Nurieva RI, Chung Y, Martinez GJ, Yang XO, Tanaka S, Matskevitch TD et al. Bcl6 mediates the development of $T$ follicular helper cells. Science 2009; 325: 1001-1005.

99 Pasare C, Medzhitov R. Toll pathway-dependent blockade of $\mathrm{CD} 4{ }^{+} \mathrm{CD} 25^{+} \mathrm{T}$ cellmediated suppression by dendritic cells. Science 2003; 299: 1033-1036.

100 Yang XO, Nurieva R, Martinez GJ, Kang HS, Chung Y, Pappu BP et al. Molecular antagonism and plasticity of regulatory and inflammatory $\mathrm{T}$ cell programs. Immunity 2008; 29: 44-56.

$101 \mathrm{Xu}$ L, Kitani A, Fuss I, Strober W. Cutting edge: regulatory T cells induce CD4 ${ }^{+} \mathrm{CD} 25^{-}$Foxp $^{-} \mathrm{T}$ cells or are self-induced to become Th17 cells in the absence of exogenous TGF-beta. J Immunol 2007; 178: 6725-6729.

102 Zhou L, Lopes JE, Chong MM, Ivanov, II, Min R, Victora GD et al. TGF-beta-induced Foxp3 inhibits $\mathrm{T}(\mathrm{H}) 17$ cell differentiation by antagonizing RORgammat function. Nature 2008; 453: 236-240.

103 Zeng WP, Chang C, Lai JJ. Immune suppressive activity and lack of T helper differentiation are differentially regulated in natural regulatory T cells. J Immunol 2009; 183: 3583-3590.

104 Wei G, Wei L, Zhu J, Zang C, Hu-Li J, Yao Z et al. Global mapping of H3K4me3 and H3K27me3 reveals specificity and plasticity in lineage fate determination of differentiating $\mathrm{CD}^{+}{ }^{+} \mathrm{T}$ cells. Immunity 2009; 30: 155-167.

105 Mantel PY, Kuipers H, Boyman O, Rhyner C, Ouaked N, Ruckert B et al. GATA3-driven Th2 responses inhibit TGF-beta1-induced FOXP3 expression and the formation of regulatory T cells. PLoS Biol 2007; 5: e329.

106 Dardalhon V, Awasthi A, Kwon H, Galileos G, Gao W, Sobel RA et al. IL-4 inhibits TGFbeta-induced Foxp $3^{+}$T cells and, together with TGF-beta, generates IL- $9^{+}$IL-10 Foxp3- effector T cells. Nat Immunol 2008; 9: 1347-1355.

107 Veldhoen M, Uyttenhove C, van Snick J, Helmby H, Westendorf A, Buer J et al. Transforming growth factor-beta 'reprograms' the differentiation of T helper 2 cells and promotes an interleukin 9-producing subset. Nat Immunol 2008; 9: 1341-1346. 
108 Gavin MA, Rasmussen JP, Fontenot JD, Vasta V, Manganiello VC, Beavo JA et al. Foxp3-dependent programme of regulatory T-cell differentiation. Nature 2007; 445: 771-775

109 Zhou X, Bailey-Bucktrout SL, Jeker LT, Penaranda C, Martinez-Llordella M, Ashby M et al. Instability of the transcription factor Foxp3 leads to the generation of pathogenic memory T cells in vivo. Nat Immunol 2009; 10: 1000-1007.

110 Oldenhove G, Bouladoux N, Wohlfert EA, Hall JA, Chou D, Dos Santos L et al. Decrease of Foxp $3^{+}$Treg cell number and acquisition of effector cell phenotype during lethal infection. Immunity 2009; 31: 772-786.
111 Tsuji M, Komatsu N, Kawamoto S, Suzuki K, Kanagawa O, Honjo T et al. Preferential generation of follicular B helper T cells from Foxp $3^{+} \mathrm{T}$ cells in gut Peyer's patches. Science 2009; 323: 1488-1492.

112 Wan YY, Flavell RA. Regulatory T-cell functions are subverted and converted owing to attenuated Foxp3 expression. Nature 2007; 445: 766-770.

113 Ansel KM, Lee DU, Rao A. An epigenetic view of helper T cell differentiation. Nat Immunol 2003; 4: 616-623.

114 Wilson CB, Rowell E, Sekimata M. Epigenetic control of T-helper-cell differentiation. Nat Rev Immunol 2009; 9: 91-105. 